\title{
Geneticists chip away at unruly data
}

Erika Check, Washington

Researchers in genetics trying to share their results face an uphill struggle. The wide range of experimental methods that they use makes it fiendishly hard to compare data. But a consortium of companies and academics is now working with the US government to tackle the problem by drawing up a better standards system.

The External RNA Controls Consortium (ERCC) says that such standards will allow geneticists to reach more accurate conclusions, and to compare their data with the findings of others.

"There is definitely a need for standardization," says Gavin Sherlock, a geneticist at Stanford University in California. "It's one of the biggest problems we have - there is no way of connecting the dots between two platforms very well."

The bulk of genetics research involves characterizing the genes expressed by a particular cell or tissue under specific experimental conditions. But there are many ways to do this, and researchers say that they can get different results from the same experiment depending on the method they use. They can even have problems duplicating their own results from the same technology.

The ERCC is addressing the issue by setting up standard controls for checking the performance of experiments. The group is drawing up an extensive list of genetic sequences that won't normally turn up in most studies. Pieces of genetic material that

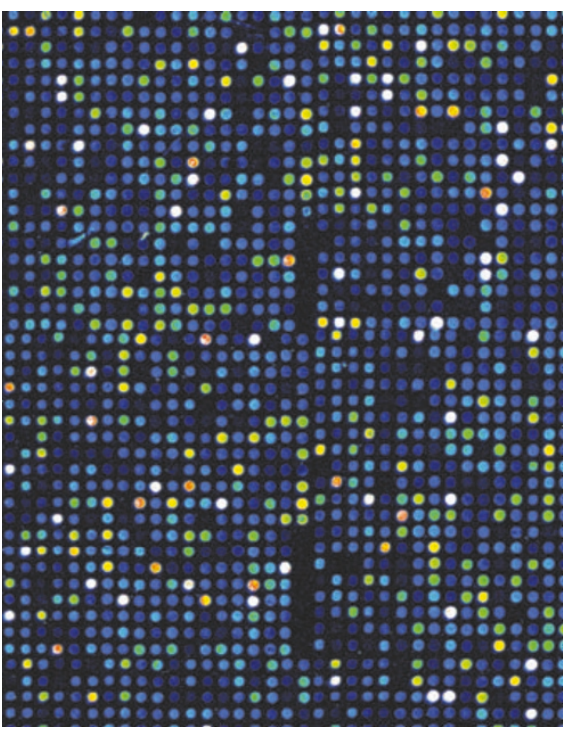

Sharing nature: fresh standards should make it easier to compare results from microarrays.

correspond to these sequences will then be manufactured for use as controls, allowing geneticists to test how well they are detected in their laboratories. Researchers will then be able to compare the results of different experiments with more confidence, consortium members say.

The ERCC held two workshops last year, and gene-chip manufacturers such as Affymetrix, based in Santa Clara, California, are already gearing up to produce the materials that the plan requires. Marc Salit of the
National Institute of Standards and Technology, which helped to organize the workshops, says that a non-profit means will probably be established to distribute the controls. He says that in the most optimistic scenario, the materials could be available within a year to 18 months.

The ERCC was set up in the wake of a standardization effort led by the Microarray Gene Expression Data Society, a group of scientists that has drawn up a common language for comparing gene-expression experiments and which is now devising data formats to help researchers to compare their results (see Nature 415, 946; 2002).

Janet Warrington, vice-president of Affymetrix, says that one of the ERCC's goals is to move genetics closer to the clinic. Making sophisticated genetic analysis accessible to physicians will require much smoother standardization than now exists, she says: "If you're going to develop something for clinical application, you really want to look into developing standards."

Researchers say that the ERCC's work will be a big help, but will not entirely solve the problem of standardization. For instance, says John Quackenbush, a bioinformatician at The Institute for Genomic Research in Rockville, Maryland, the consortium's efforts are primarily focused on experiments in humans, so research in other organisms could be left out in the cold. "Will it solve all the problems? Absolutely not," Quackenbush says. "But it's a very important first step."

\section{Canadian prime minister makes science a priority}

David Spurgeon, Montreal Scientists in Canada are feeling a rush of optimism over the words and actions of the new prime minister, Paul Martin, who says that if he was born again, he'd like to come back as a basic researcher.

Martin, who succeeded fellow Liberal Jean Chretien

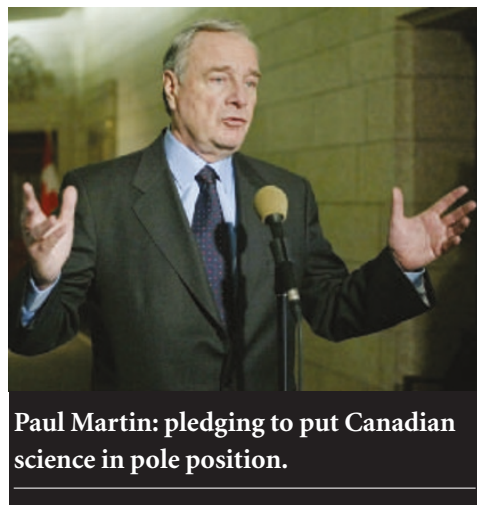

Arthur Carty, president of the National Research Council Canada, the country's main research and development agency, as his full-time science adviser - the first such appointment in Canada for 30 years. Martin also says that he plans to chair a new cabinet committee to set scientific priorities, and will work to revitalize the Advisory Council on on 12 December, first made the remark in a recorded message to his supporters. The comment was then repeated in a November newspaper interview, in which Martin vowed to make science and technology a central pillar of government policy. "I'm making it a fundamental tenet of my government," he told the Toronto Star.

On the day he took office, Martin named
Science and Technology, an external panel that has had a low profile in recent years. In addition, he has appointed seasoned politician Joe Fontana as parliamentary secretary for science and small business.

John Polanyi, a chemist at the University of Toronto who won the Nobel prize in $\mathbf{1 9 8 6}$ for his work on reaction dynamics, says that Martin's first month in office is "a hopeful moment in the history of Canadian science". But he cautions that Martin will have to resist pressure to over-commercialize research, especially at universities. "Our scientists are becoming less effective because of baroque schemes for milking science of its wealth-creating aspect," he complains.

Martin was finance minister when Chretien's government reversed cuts that had hampered the three federal agencies that fund most university research, and found billions of dollars for such initiatives as the Canada Foundation for Innovation.

In a speech in Montreal in October, Martin hinted at a more commercial approach to research policy, calling for " $a$ fundamental change in the way that our research institutions assess the economic potential of their discoveries". But he later added that "basic research that does nothing else but expand the sum of human knowledge is sufficient reward in itself for the expenditure that government puts in." 